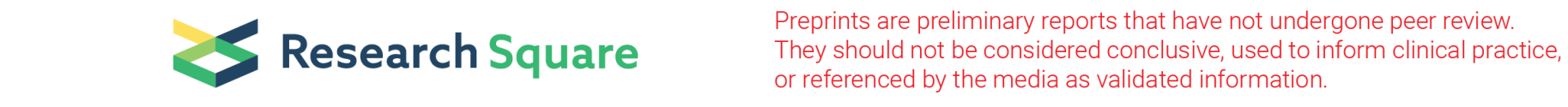

\title{
Determination of Appropriate Personal Protective Equipment for Management of Patients With COVID-19
}

Jongtak Jung

Seoul National University Bundang Hospital

Kyoung-Ho Song ( $\sim$ khsongmd@gmail.com)

Seoul National University Bundang Hospital https://orcid.org/0000-0002-4517-3840

Hyeonju Jeong

Seoul National University Bundang Hospital

Sin Young Ham

Seoul National University Bundang Hospital

Eu Suk Kim

Seoul National University Bundang Hospital

Hong Bin Kim

Seoul National University Bundang Hospital

\section{Short report}

Keywords: severe acute respiratory syndrome coronavirus 2, coronavirus disease, personal protective equipment

Posted Date: June 8th, 2021

DOI: https://doi.org/10.21203/rs.3.rs-582652/v1

License: (c) (i) This work is licensed under a Creative Commons Attribution 4.0 International License. Read Full License 


\section{Abstract \\ Objectives}

Few studies have investigated the contamination of personal protective equipment (PPE) during the management of patients with severe to critical coronavirus disease (COVID-19). This study aimed to determine the necessity of coveralls and foot cover for body protection during the management of patients with COVID-19.

\section{Methods}

PPE samples were collected from physicians exiting a room after the management of a patient with severe to critical COVID-19 who was within 14 days after symptom onset. The PPE sites were categorized into coverall-only parts (the frontal surface of the head, anterior neck, dorsal surface of the foot cover, and back and hip) and gown-covered parts (the anterior side of the forearm and the abdomen). Environmental sampling was performed in patient rooms. We tried to identify significant differences in contamination with severe acute respiratory syndrome coronavirus 2 (SARS-CoV-2) between the coverall-only and gown-covered parts.

\section{Results}

A total of 105 swabs from PPE and 28 swabs from patient rooms were collected. Of the PPE swabs, only three (2.8\%) swabs from gowncovered parts were contaminated by SARS-CoV-2. However, 23 of the total 28 sites (82.1\%) from patient rooms were contaminated. There was significant difference in the contamination of PPE between coverall-only and gown-covered parts ( $0.0 \mathrm{vs} 6.7 \%, p=0.022)$.

\section{Conclusions}

Coverall contamination rarely occurred while managing severe to critical COVID-19 patients residing in negative pressure rooms in the early stages of the illness. Long-sleeved gowns may be used safely in the management of COVID-19 patients.

\section{Introduction}

The World Health Organization (WHO) recommends the rational use of personal protective equipment (PPE) according to the setting, personnel, and type of activity, because of the recent global shortage of PPE [1]. The WHO recommends the use of medical masks, goggles or facial shields, gowns, and gloves when providing direct care to patients with coronavirus disease (COVID-19) in the absence of aerosol generating procedures (AGPs) [1]. However, discrepancy was observed between international and local guidelines with regards to the social circumstances [2]. Initially, the Korea Centers for Disease Control and Prevention recommended the use of coveralls and foot covers for body protection, but after several updates, it is recommended to use either a coverall or a water-resistant long-sleeves gown during the management of patients with COVID-19 [2]. Although recent evidence suggests that the transmission of severe acute respiratory syndrome coronavirus 2 (SARS-CoV-2) through contact with fomite is rare [3, 4], there are still concerns about viral contamination; thus, many hospitals in Korea still use coveralls with foot covers rather than gowns for body protection while managing patients with COVID-19 [5].

The research indicates that the PPE of healthcare workers is not contaminated extensively in the management of patients with COVID-19 [611], but few studies have investigated the contamination of PPE during the management of patients with severe to critical COVID-19. Therefore, we conducted this pilot study to determine the necessity of coveralls for body protection during the management of patients with severe to critical COVID-19 in the early stages of the illness.

\section{Methods}

\section{Study design and patients}

This study was conducted in an academic medical center in the Republic of Korea. All patients involved this study were managed in isolated negative pressure rooms. The ventilation rate in the negative pressure room was 20 air changes per hour. Routine room cleaning and disinfection of high contact areas around patient environment were performed daily using sodium hypochlorite.

Between February 17 and April 19, 2021, patients with severe to critical COVID-19 who were within 14 days after symptom onset were included. If supplementary oxygen was required in patients with radiologic pneumonia, they were classified as having severe disease, and 
patients with severe oxygenation impairment $\left(\mathrm{PaO}_{2} / \mathrm{FiO}_{2}\right.$ of $\left.\leq 300\right)$ were classified as having critical disease according to the WHO classification [12].

\section{Sample and data collection and analysis}

PPE samples were acquired from seven sites of 15 physicians exiting from nine patient rooms. The sampled sites comprised the frontal surface of the head, anterior neck, anterior side of forearm, abdomen, dorsal surface of the foot cover, and back and hip (Fig. 1). To assess environmental contamination, we acquired samples from seven sites of four patient rooms. The environmental sampling sites were the bed linen around the patient's head, bed controller, both side rails, remote control for the television, call-button, and bed-side table (Fig. 2). Premoistened sterile swabs were used to collect samples in $20 \times 20 \mathrm{~cm}$ areas. Real-time reverse transcriptase-polymerase chain reaction (RT-PCR) targeting E, S, RdRP/S genes was used to detect SARS-CoV-2 (Allplex ${ }^{\text {TM }}$ SARS-COV-2 Assay, Seegene Inc.) [13]. Clinical data (day of illness, symptoms, disease severity, RT-PCR results of respiratory specimens) were collected. Activities and spending time of physicians in the patient room were recorded.

Coveralls cover the whole body including the head, lower legs, and back side of the body, but long-sleeved gowns do not cover the head and lower legs, and protection of the back side is compromised because of the open back design. To identify the necessity of coveralls for body protection, the PPE sites were classified into coverall-only parts (the frontal surface of the head, anterior neck, dorsal surface of the foot cover, and back and hip) and gown-covered parts (the anterior side of the forearm and the abdomen) (Fig. 1). Fisher's exact test was used to identify differences in contamination between the two parts. A p-value of $<0.05$ was considered statistically significant.

\section{Results}

A total of 105 swabs from PPE and 28 swabs from the environment were collected. The median of sampling days from symptom onset was 9 days (range 2-12 days). The median of sampling days from admission was 3 days (range 1-7 days). The median contact time with patients was $20 \mathrm{~min}$ (range 10-30 min). Activities commonly performed by physicians in the patient room were general care, physical examination, and acquisitions of respiratory samples. AGPs such as intubation, suctioning of airway, or nebulizer therapy were performed in five cases. Of the PPE swabs, only three (two from the abdomen and one from the forearm) were contaminated by SARS-CoV-2. All swabs from the coverallonly parts were negative. There was a significant difference in the contamination of PPE between the coverall-only and gown-covered parts ( 0.0 vs $6.7 \%, p=0.022$ ). The detailed clinical information regarding the included patients and contamination of PPE are shown in Table 1. Of the environment swabs, 20 or the total 28 sites (82.1\%) were contaminated. The detailed contamination sites and cycle threshold of the environment are presented in Table 2. 
Table 1

Clinical characteristics of included patients and contamination of personal protective equipment according to the type of activity and contact time

\begin{tabular}{|c|c|c|c|c|c|c|c|c|c|c|}
\hline PPE & Patient & $\begin{array}{l}\text { Type of } \\
\text { oxygen } \\
\text { delivery }\end{array}$ & $\begin{array}{l}\text { PF } \\
\text { ratio }\end{array}$ & $\begin{array}{l}\text { Sampling } \\
\text { days from } \\
\text { admission }\end{array}$ & $\begin{array}{l}\text { Sampling } \\
\text { days } \\
\text { from } \\
\text { symptom } \\
\text { onset }\end{array}$ & Type of activity & $\begin{array}{l}\text { Aerosol } \\
\text { generating } \\
\text { procedures }\end{array}$ & $\begin{array}{l}\text { Contact } \\
\text { time } \\
\text { (min) }\end{array}$ & $\begin{array}{l}\text { Ct value } \\
\text { of } \\
\text { respiratory } \\
\text { samples }\end{array}$ & $\begin{array}{l}\text { Sites of PPE } \\
\text { contamination } \\
\text { (Genes, Ct } \\
\text { value) }\end{array}$ \\
\hline 1 & A & HFNC & 73 & 5 & 10 & $\begin{array}{l}\text { Examination, } \\
\text { general care }\end{array}$ & No & 20 & 22.52 & ND \\
\hline 2 & B & HFNC & 125 & 3 & 11 & $\begin{array}{l}\text { Examination, } \\
\text { general care }\end{array}$ & No & 10 & 20.13 & ND \\
\hline 3 & $A$ & HFNC & 73 & 6 & 11 & $\begin{array}{l}\text { Examination, } \\
\text { general care, } \\
\text { acquisition of } \\
\text { nasopharyngeal } \\
\text { and lower } \\
\text { respiratory } \\
\text { sample }\end{array}$ & No & 10 & 26.54 & ND \\
\hline 4 & $A$ & MV & 72 & 7 & 12 & $\begin{array}{l}\text { Examination, } \\
\text { intubation, } \\
\text { acquisition of } \\
\text { nasopharyngeal } \\
\text { and lower } \\
\text { respiratory } \\
\text { sample, } \\
\text { suctioning of } \\
\text { airway }\end{array}$ & $\begin{array}{l}\text { Yes } \\
\text { (intubation, } \\
\text { suctioning } \\
\text { of airway) }\end{array}$ & 20 & 26.54 & ND \\
\hline 5 & C & HFNC & 94 & 1 & 9 & $\begin{array}{l}\text { Examination, } \\
\text { general care, } \\
\text { acquisition of } \\
\text { nasopharyngeal } \\
\text { and lower } \\
\text { respiratory } \\
\text { sample }\end{array}$ & No & 30 & 19.65 & ND \\
\hline 6 & C & HFNC & 94 & 1 & 9 & $\begin{array}{l}\text { Examination, } \\
\text { general care }\end{array}$ & No & 30 & 19.65 & ND \\
\hline 7 & C & HFNC & 69 & 2 & 10 & $\begin{array}{l}\text { Examination, } \\
\text { general care }\end{array}$ & No & 15 & 15.56 & $\begin{array}{l}\text { Abdomen } \\
\text { (RdRP/S } \\
38.62 \text {, E 38.17, } \\
\text { N ND) }\end{array}$ \\
\hline 8 & $\mathrm{D}$ & NP & 243 & 2 & 2 & $\begin{array}{l}\text { Examination, } \\
\text { general care, } \\
\text { suctioning of } \\
\text { airway }\end{array}$ & $\begin{array}{l}\text { Yes } \\
\text { (suctioning } \\
\text { of airway) }\end{array}$ & 15 & 13.88 & ND \\
\hline 9 & C & MV & 92 & 3 & 11 & $\begin{array}{l}\text { Examination, } \\
\text { general care, } \\
\text { acquisition of } \\
\text { nasopharyngeal } \\
\text { and lower } \\
\text { respiratory } \\
\text { sample, } \\
\text { suctioning of } \\
\text { airway }\end{array}$ & $\begin{array}{l}\text { Yes } \\
\text { (suctioning } \\
\text { of airway) }\end{array}$ & 20 & 22.19 & $\begin{array}{l}\text { Forearm } \\
\text { (RdRP/S ND, E } \\
37.91, \text { N ND) }\end{array}$ \\
\hline
\end{tabular}

PPE, personal protective equipment; PF ratio, the ratio of arterial oxygen partial pressure to fractional inspired oxygen; Ct, cycle threshold; HFNC, high flow nasal canula; MV, mechanical ventilation; ND, not detected 


\begin{tabular}{|c|c|c|c|c|c|c|c|c|c|c|}
\hline PPE & Patient & $\begin{array}{l}\text { Type of } \\
\text { oxygen } \\
\text { delivery }\end{array}$ & $\begin{array}{l}\mathrm{PF} \\
\text { ratio }\end{array}$ & $\begin{array}{l}\text { Sampling } \\
\text { days from } \\
\text { admission }\end{array}$ & $\begin{array}{l}\text { Sampling } \\
\text { days } \\
\text { from } \\
\text { symptom } \\
\text { onset }\end{array}$ & Type of activity & $\begin{array}{l}\text { Aerosol } \\
\text { generating } \\
\text { procedures }\end{array}$ & $\begin{array}{l}\text { Contact } \\
\text { time } \\
\text { (min) }\end{array}$ & $\begin{array}{l}\text { Ct value } \\
\text { of } \\
\text { respiratory } \\
\text { samples }\end{array}$ & $\begin{array}{l}\text { Sites of PPE } \\
\text { contamination } \\
\text { (Genes, Ct } \\
\text { value) }\end{array}$ \\
\hline 10 & D & HFNC & 73 & 7 & 7 & $\begin{array}{l}\text { Examination, } \\
\text { general care, } \\
\text { acquisition of } \\
\text { nasopharyngeal } \\
\text { and lower } \\
\text { respiratory } \\
\text { sample, } \\
\text { suctioning of } \\
\text { airway }\end{array}$ & $\begin{array}{l}\text { Yes } \\
\text { (suctioning } \\
\text { of airway) }\end{array}$ & 20 & 24.23 & ND \\
\hline 11 & $\mathrm{~F}$ & HFNC & 75 & 3 & 6 & $\begin{array}{l}\text { Examination, } \\
\text { general care, } \\
\text { acquisition of } \\
\text { nasopharyngeal } \\
\text { and lower } \\
\text { respiratory } \\
\text { sample }\end{array}$ & No & 30 & 22.63 & ND \\
\hline 12 & G & HFNC & 150 & 2 & 5 & $\begin{array}{l}\text { Examination, } \\
\text { general care, } \\
\text { acquisition of } \\
\text { nasopharyngeal } \\
\text { and lower } \\
\text { respiratory } \\
\text { sample }\end{array}$ & No & 20 & 16.87 & ND \\
\hline 13 & G & HFNC & 113 & 5 & 8 & $\begin{array}{l}\text { Examination, } \\
\text { general care, } \\
\text { acquisition of } \\
\text { nasopharyngeal } \\
\text { and lower } \\
\text { respiratory } \\
\text { sample, } \\
\text { nebulizer }\end{array}$ & $\begin{array}{l}\text { Yes } \\
\text { (nebulizer) }\end{array}$ & 20 & 22.09 & ND \\
\hline 14 & $\mathrm{H}$ & HFNC & 108 & 5 & 10 & $\begin{array}{l}\text { Examination, } \\
\text { general care, } \\
\text { acquisition of } \\
\text { nasopharyngeal } \\
\text { and lower } \\
\text { respiratory } \\
\text { sample }\end{array}$ & No & 20 & 19.10 & ND \\
\hline 15 & I & HFNC & 110 & 2 & 8 & $\begin{array}{l}\text { Examination, } \\
\text { general care, } \\
\text { acquisition of } \\
\text { nasopharyngeal } \\
\text { and lower } \\
\text { respiratory } \\
\text { sample }\end{array}$ & No & 30 & 21.43 & $\begin{array}{l}\text { Abdomen } \\
\text { (RdRP/S } \\
37.91 \text {, E ND, N } \\
\text { ND) }\end{array}$ \\
\hline
\end{tabular}


Table 2

Severe acute respiratory syndrome coronavirus 2 contamination of the environment

\begin{tabular}{|c|c|c|c|c|c|c|c|c|c|}
\hline \multirow[t]{2}{*}{ Patient } & \multirow{2}{*}{$\begin{array}{l}\text { Sampling days } \\
\text { from admission }\end{array}$} & \multirow{2}{*}{$\begin{array}{l}\text { Sampling days from } \\
\text { symptom onset }\end{array}$} & \multicolumn{7}{|c|}{ Environmental contamination (Ct value) } \\
\hline & & & $\begin{array}{l}\text { Bed } \\
\text { linen }\end{array}$ & $\begin{array}{l}\text { Bed } \\
\text { controller }\end{array}$ & $\begin{array}{l}\text { Bedrail, } \\
\text { right }\end{array}$ & $\begin{array}{l}\text { Bedrail, } \\
\text { left }\end{array}$ & $\begin{array}{l}\text { Remote } \\
\text { control }\end{array}$ & $\begin{array}{l}\text { Call } \\
\text { button }\end{array}$ & $\begin{array}{l}\text { Bedside } \\
\text { table }\end{array}$ \\
\hline \multirow[t]{4}{*}{$\mathrm{F}$} & \multirow[t]{4}{*}{3} & \multirow[t]{4}{*}{6} & \multirow[t]{4}{*}{ ND } & \multirow{2}{*}{$\begin{array}{l}\text { E (33.87) } \\
\text { RdRP/S } \\
(34.19)\end{array}$} & $\mathrm{E}$ & \multirow[t]{4}{*}{ ND } & \multirow[t]{4}{*}{ ND } & E $(3806)$ & E \\
\hline & & & & & \multirow{2}{*}{$\begin{array}{l}\text { RdRP/S } \\
(38.05)\end{array}$} & & & \multirow{2}{*}{$\begin{array}{l}\mathrm{RdRP} / \mathrm{S} \\
(38.64)\end{array}$} & \multirow{2}{*}{$\begin{array}{l}\text { RdRP/S } \\
(39.03)\end{array}$} \\
\hline & & & & $\mathrm{N}(32.09)$ & & & & & \\
\hline & & & & & $\begin{array}{l}\mathrm{N} \\
(38.11)\end{array}$ & & & $\begin{array}{l}\mathrm{N} \\
(37.90)\end{array}$ & $N(N D)$ \\
\hline \multirow[t]{3}{*}{ G } & \multirow[t]{3}{*}{2} & \multirow[t]{3}{*}{5} & $\begin{array}{l}E \\
(35.50)\end{array}$ & \multirow{2}{*}{$\begin{array}{l}\text { E (37.59) } \\
\text { RdRP/S } \\
(37.75)\end{array}$} & $\begin{array}{l}\mathrm{E} \\
(35.15)\end{array}$ & $\begin{array}{l}\mathrm{E} \\
(34.94)\end{array}$ & $\begin{array}{l}\mathrm{E} \\
(33.38)\end{array}$ & $\begin{array}{l}\mathrm{E} \\
(33.82)\end{array}$ & $\begin{array}{l}\mathrm{E} \\
(37.94)\end{array}$ \\
\hline & & & $\begin{array}{l}\text { RdRP/S } \\
(36.60)\end{array}$ & & $\begin{array}{l}\text { RdRP/S } \\
(35.17)\end{array}$ & $\begin{array}{l}\text { RdRP/S } \\
(37.61)\end{array}$ & $\begin{array}{l}\text { RdRP/S } \\
(35.19)\end{array}$ & $\begin{array}{l}\mathrm{RdRP} / \mathrm{S} \\
(34.37)\end{array}$ & $\begin{array}{l}\mathrm{RdRP} / \mathrm{S} \\
\text { (ND) }\end{array}$ \\
\hline & & & $\begin{array}{l}\mathrm{N} \\
(35.02)\end{array}$ & $N(35.01)$ & $\begin{array}{l}\mathrm{N} \\
(33.64)\end{array}$ & $\begin{array}{l}\mathrm{N} \\
(35.60)\end{array}$ & $\begin{array}{l}\mathrm{N} \\
(33.22)\end{array}$ & $\begin{array}{l}\mathrm{N} \\
(34.08)\end{array}$ & $\begin{array}{l}\mathrm{N} \\
(37.17)\end{array}$ \\
\hline \multirow[t]{3}{*}{$\mathrm{H}$} & \multirow[t]{3}{*}{5} & \multirow[t]{3}{*}{10} & $\begin{array}{l}\mathrm{E} \\
(31.25)\end{array}$ & \multirow{2}{*}{$\begin{array}{l}\text { E (35.31) } \\
\text { RdRP/S } \\
(35.14)\end{array}$} & $\begin{array}{l}\mathrm{E} \\
(36.80)\end{array}$ & $\begin{array}{l}\mathrm{E} \\
(36.99)\end{array}$ & $\begin{array}{l}\mathrm{E} \\
(36.26)\end{array}$ & \multirow[t]{3}{*}{ ND } & $\begin{array}{l}\mathrm{E} \\
(35.70)\end{array}$ \\
\hline & & & $\begin{array}{l}\text { RdRP/S } \\
(31.40)\end{array}$ & & $\begin{array}{l}\text { RdRP/S } \\
(37.99)\end{array}$ & $\begin{array}{l}\text { RdRP/S } \\
(35.71)\end{array}$ & $\begin{array}{l}\mathrm{RdRP} / \mathrm{S} \\
(35.64)\end{array}$ & & $\begin{array}{l}\text { RdRP/S } \\
(35.66)\end{array}$ \\
\hline & & & $\begin{array}{l}\mathrm{N} \\
(32.23)\end{array}$ & $N(34.32)$ & $\begin{array}{l}\mathrm{N} \\
(36.70)\end{array}$ & $\begin{array}{l}\mathrm{N} \\
(37.03)\end{array}$ & $\begin{array}{l}\mathrm{N} \\
(37.50)\end{array}$ & & $\begin{array}{l}\mathrm{N} \\
(36.29)\end{array}$ \\
\hline \multirow[t]{3}{*}{ I } & \multirow[t]{3}{*}{2} & \multirow[t]{3}{*}{8} & $\begin{array}{l}\mathrm{E} \\
(38.22)\end{array}$ & \multirow{2}{*}{$\begin{array}{l}\text { E (35.99) } \\
\text { RdRP/S } \\
(37.55)\end{array}$} & $\begin{array}{l}E \\
(35.84)\end{array}$ & $\begin{array}{l}\mathrm{E} \\
(35.73)\end{array}$ & $\begin{array}{l}\mathrm{E} \\
(34.36)\end{array}$ & $\begin{array}{l}\mathrm{E} \\
(34.59)\end{array}$ & ND \\
\hline & & & $\begin{array}{l}\text { RdRP/S } \\
(36.64)\end{array}$ & & $\begin{array}{l}\text { RdRP/S } \\
(36.17)\end{array}$ & $\begin{array}{l}\text { RdRP/S } \\
(36.93)\end{array}$ & $\begin{array}{l}\mathrm{RdRP} / \mathrm{S} \\
(35.84)\end{array}$ & $\begin{array}{l}\mathrm{RdRP} / \mathrm{S} \\
(34.01)\end{array}$ & \\
\hline & & & $\mathrm{N}(\mathrm{ND})$ & N (35.36) & $\begin{array}{l}\mathrm{N} \\
(37.11)\end{array}$ & $\begin{array}{l}\mathrm{N} \\
(36.34)\end{array}$ & $\begin{array}{l}\mathrm{N} \\
(33.85)\end{array}$ & $\begin{array}{l}\mathrm{N} \\
(35.79)\end{array}$ & \\
\hline
\end{tabular}

\section{Discussion}

This study aimed to determine the necessity of coveralls for body protection during the management of patients with severe to critical COVID19 in the early stages of the illness. Our results revealed that coverall contamination rarely occurred during the management of patients with severe to critical COVID-19 in the early stages of the illness, although environmental contamination was common. In particular, the coverallonly parts were not contaminated.

In previous studies, PPE contamination was not observed during the management of asymptomatic or mild COVID-19 patients [8-10]. In some studies $[6,7,11]$, some parts of the PPE, even on the top of the head or foot covers, were contaminated during the routine care of patients over an extended period (4 h) [7], but most parts of the PPE were not contaminated, and the viability of virus was not confirmed.

Donning coveralls requires more time than donning long-sleeve gowns, which makes it difficult to respond to emergency situations. Further, because coveralls cover the whole body, they can induce heat stress more easily than gowns, causing dehydration and exhaustion, which may influence performance [14]. In addition, coveralls are not familiar to healthcare workers and contamination occurs frequently during the doffing process, meaning regular training is required $[15,16]$. Inadequate and overuse of PPE shown in mass media can cause excess fear in the general public, leading to social issues such as mental health problems and stigma [17-19]. Considering the disadvantages of coveralls and global shortage of PPE, protective clothing should be reasonably used according to the risk of contamination. 
Because contamination of PPE, particularly the coverall-only parts, rarely occurred during the short-term management of COVID-19 patients regardless of disease severity, it can be expected that long-sleeved gowns could provide sufficient protection from SARS-CoV-2 contamination. Recent evidence suggests that the dominant route of viral transmission is via the respiratory tract by droplet or aerosol and that transmission through contact with fomite is rare $[3,4,20]$; therefore, the use of long-sleeved gowns in conjunction with hand hygiene and routine cleaning and disinfection of the hospital environment may protect healthcare workers from SARS-CoV-2 infection during the management of patients with COVID-19.

This study has some limitations. First, although we acquired samples from PPE in various situations including AGPs, the sample size was relatively small, and these results cannot be extrapolated to the case of managing patients at high risk of airborne transmission. Second, as this study was conducted only in isolated negative pressure rooms with high ventilation rates, further study is needed to identify contamination of PPE when managing patients admitted to general wards without negative pressure.

\section{Conclusion}

In the present study, we found that coverall contamination rarely occurred while managing severe to critical COVID-19 patients admitted to negative pressure rooms in the early stages of the illness. Long-sleeved gowns may be used safely when managing COVID-19 patients.

\section{List Of Abbreviations}

World Health Organization (WHO), personal protective equipment (PPE), coronavirus disease (COVID-19), aerosol generating procedures (AGPs), severe acute respiratory syndrome coronavirus 2 (SARS-CoV-2), reverse transcriptase-polymerase chain reaction (RT-PCR)

\section{Declarations}

\section{Ethics approval and consent to participate}

The study was approved by the institutional review board (IRB) of Seoul National University Bundang Hospital (B-2006/619-105). The requirement for informed consent was waived by IRB.

\section{Consent for publication}

Not applicable.

\section{Availability of data and materials}

The datasets used and/or analyzed during the study are available from the corresponding author on reasonable request.

\section{Competing interests}

There are no conflicts of interest to declare.

\section{Funding}

This work was supported by grant No. 02-2020-020 from the SNUBH Research Fund.

\section{Author's contributions}

Conceptualization, Methodology, Writing - original draft, Investigation, Data curation, Formal analysis: J.J, K.H.S, H.J.J, H.S.Y. Acquisition of swab samples: J.J, H.J.J, H.S.Y. Data interpretation, Writing - review \& editing: H.J.J, H.S.Y., E.S.K, H.B.K., K.H.S. All authors have provided final approval for the final version of the manuscript.

\section{Acknowledgments}

We would like to thank Editage (www.editage.co.kr) for English language editing

\section{References}

1. World Health Organization. Rational use of personal protective equipment for COVID-19 and considerations during severe shortages: interim guidance, 23 December 2020. Available from: https://www.who.int/publications/i/item/rational-use-of-personal-protectiveequipment-for-coronavirus-disease-(covid-19)-and-considerations-during-severe-shortages. 
2. Park SH. Personal protective equipment for healthcare workers during the COVID-19 pandemic. Infection chemotherapy $2020,52(2): 165$.

3. Kampf G, Brüggemann Y, Kaba HE, Steinmann J, Pfaender S, Scheithauer S, Steinmann E. Potential sources, modes of transmission and effectiveness of prevention measures against SARS-CoV-2. Journal of Hospital Infection 2020, 106:678-697

4. Meyerowitz EA, Richterman A, Gandhi RT, Sax PE. Transmission of SARS-CoV-2: a review of viral, host, and environmental factors. Annals of internal medicine. 2021;174:69-79.

5. W Jang, B Kim, ES Kim, KH Song, SM Moon, MJ Lee, JY Park, JY Kim, MJ Shin, KB Stevenson, HB Kim, Strategies for prevention of COVID-19 transmission in the hospital setting. E-poster presented at : 26th Congr of Korean Soc for Healthc Assoc Infect Control Preve, 2021 May 27-28

6. Aumeran C, Henquell C, Brebion A, Noureddine J, Traore O, Lesens O. Isolation gown contamination during healthcare of confirmed SARSCoV-2-infected patients. Journal of Hospital Infection 2021, 107:111-113.

7. Jung J, Kim JY, Bae S, Cha H-H, Kim EO, Kim MJ, Kim S-H. Contamination of personal protective equipment by SARS-CoV-2 during routine care of patients with mild COVID-19. Journal of Infection 2020, 81(2):e165-e167.

8. Ong SWX, Tan YK, Chia PY, Lee TH, Ng OT, Wong MSY, Marimuthu K. Air, surface environmental, and personal protective equipment contamination by severe acute respiratory syndrome coronavirus 2 (SARS-CoV-2) from a symptomatic patient. Jama 2020, 323(16):16101612.

9. Ong SWX, Tan YK, Sutjipto S, Chia PY, Young BE, Gum M, Lau SK, Chan M, Vasoo S, Mendis S. Absence of contamination of personal protective equipment (PPE) by severe acute respiratory syndrome coronavirus 2 (SARS-CoV-2). Infection Control 2020, 41(5):614-616.

10. Wei L, Huang W, Lu X, Wang Y, Cheng L, Deng R, Long H, Zong Z. Contamination of SARS-CoV-2 in patient surroundings and on personal protective equipment in a non-ICU isolation ward for COVID-19 patients with prolonged PCR positive status. Antimicrobial Resistance Infection Control 2020, 9(1):1-5.

11. Yung CF, Kam K-q, Wong MS, Maiwald M, Tan YK, Tan BH, Thoon KC. Environment and personal protective equipment tests for SARSCoV-2 in the isolation room of an infant with infection. Annals of internal medicine 2020, 173(3):240-242.

12. World Health Organization. COVID-19 clinical management: living guidance, 25 January 2021. Available from: https://www.who.int/publications/i/item/WHO-2019-nCoV-clinical-2021-1.

13. Farfour E, Lesprit P, Visseaux B, Pascreau T, Jolly E, Houhou N, Mazaux L, Asso-Bonnet M, Vasse M, group S-C-FHs. The Allplex 2019-nCoV (Seegene) assay: which performances are for SARS-CoV-2 infection diagnosis? European Journal of Clinical Microbiology Infectious Diseases 2020, 39:1997-2000.

14. Davey SL, Lee BJ, Robbins T, Randeva H, Thake CD. Heat stress and PPE during COVID-19: impact on healthcare workers' performance, safety and well-being in NHS settings. Journal of Hospital Infection 2021, 108:185-188.

15. Phan LT, Maita D, Mortiz DC, Weber R, Fritzen-Pedicini C, Bleasdale SC, Jones RM, Program CPE. Personal protective equipment doffing practices of healthcare workers. Journal of occupational environmental hygiene 2019, 16(8):575-581.

16. Suen LK, Guo YP, Tong DW, Leung PH, Lung D, Ng MS, Lai TK, Lo KY, Au-Yeung CH, Yu W. Self-contamination during doffing of personal protective equipment by healthcare workers to prevent Ebola transmission. Antimicrobial Resistance Infection Control 2018, 7(1):1-9.

17. Gao J, Zheng P, Jia Y, Chen H, Mao Y, Chen S, Wang Y, Fu H, Dai J. Mental health problems and social media exposure during COVID-19 outbreak. Plos one 2020, 15(4):e0231924.

18. World Health Organization. A guide to preventing and addressing social stigma associated with COVID-19, Update 24 February 2020. Available from: https://www.who.int/publications/m/item/a-guide-to-preventing-and-addressing-social-stigma-associated-with-covid-19.

19. Villa S, Jaramillo E, Mangioni D, Bandera A, Gori A, Raviglione MC. Stigma at the time of the COVID-19 pandemic. Clinical Microbiology Infection 2020, 26(11):1450-1452.

20. Greenhalgh T, Jimenez JL, Prather KA, Tufekci Z, Fisman D, Schooley RJTL. Ten scientific reasons in support of airborne transmission of SARS-CoV-2. The Lancet 2021, 397(10285):1603-1605.

\section{Figures}




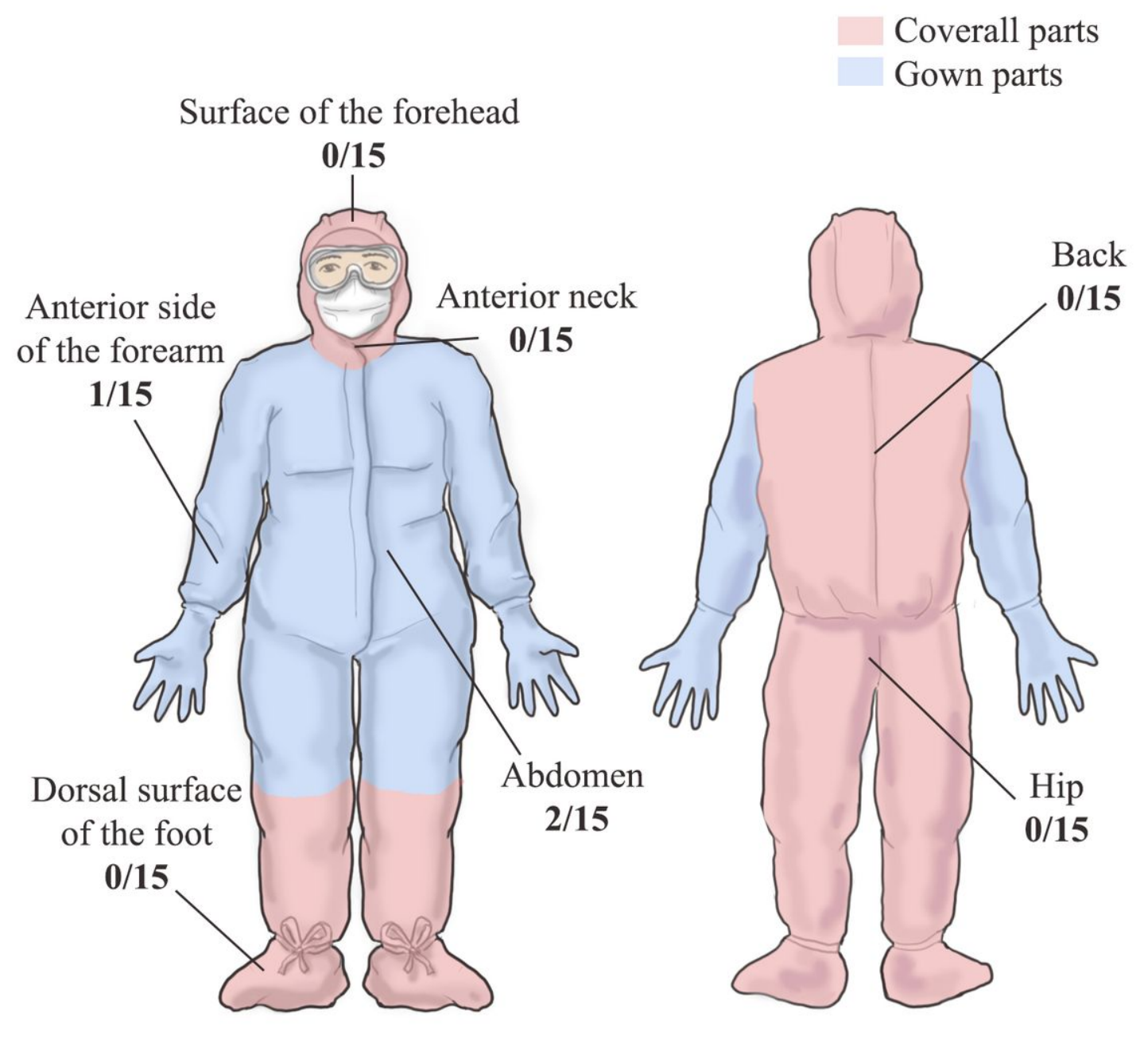

Figure 1

Sampled sites of coverall and contamination by severe acute respiratory syndrome coronavirus 2 . The proportions of contaminated samples to the total collected samples are indicated at each sampled site. 


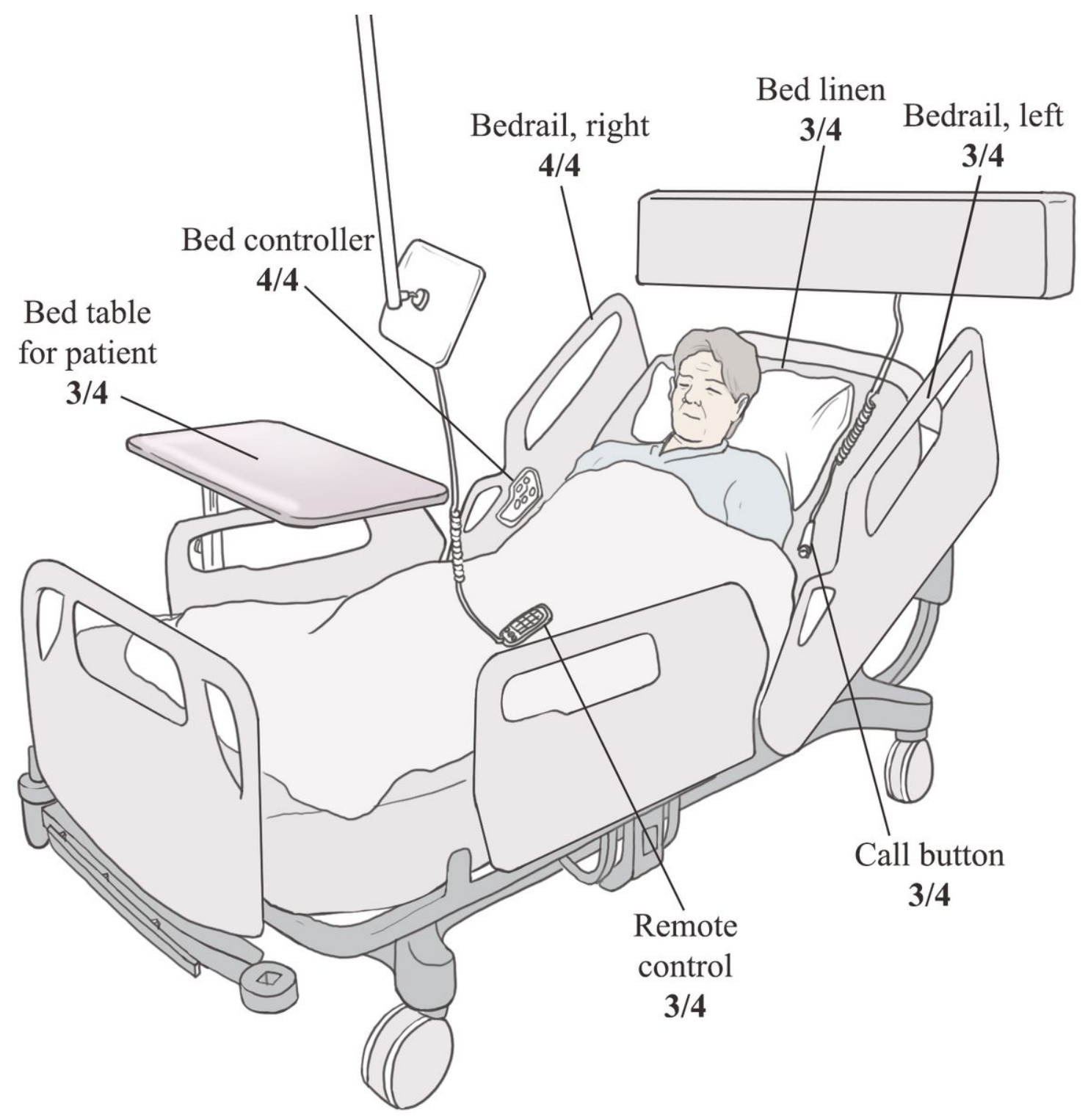

Figure 2

Sampled sites of environment around the patient and contamination by severe acute respiratory syndrome coronavirus-2. The proportions of contaminated samples to the total collected samples are indicated at each sampled site. 